\title{
Scriptures in the Study of G. I. Gurdjieff and the "Work"
}

\author{
Carole M. Cusack
}

University of Sydney

carole.cusack@sydney.edu.au

\section{Introduction}

George Ivanovich Gurdjieff (c. 1866-1949) and the teaching he founded (the Work or the Fourth Way) are hailed as a major site of contemporary esotericism and the inspiration for aspects of "New Age" spiritualities (Wellbeloved 2005). Yet the academic study of Gurdjieff was slow to develop, and arguably still lags behind that of Helena Petrovna Blavatsky and Theosophy, or Rudolf Steiner and Anthroposophy (Petsche 2011). James Webb's The Harmonious Circle: The Lives and Work of G. I. Gurdjieff, P. D. Ouspensky and Their Followers (Webb 1980) is an important precursor, and James Moore's impressive Gurdjieff: The Anatomy of a Myth (1991) is the finest "hagiographical" treatment authored by a Work insider. Since the publication of Andrew Rawlinson's The Book of Enlightened Masters: Western Teachers in Eastern Traditions (1997), the academic approach to Gurdjieff has gained momentum. In the decade leading up to 2021 a body of scholarship has been established (Azize 2013; Pittman 2012; Pecotic and Cusack 2016; Seamon 2020), and in 2021 a group of international scholarly collaborators exists. ${ }^{1}$

This issue of Postscripts: The Journal of Sacred Texts, Cultural Histories, and Contemporary Contexts features five articles focused on the place of texts in the Gurdjieff teaching. In an important sense it germinated at a symposium held at the University of Sydney on 3 December 2019, "Studying G.

1. The group consists of Joseph Azize, Carole M. Cusack, Johanna J. M. Petsche, Vrasidas Karalis and David J. Pecotic (University of Sydney), Steven J. Sutcliffe and John Willmett (University of Edinburgh), Christian Giudice (University of Gothenburg), Anthony G. E. Blake (DuVersity), David G. Robertson (The Open University, UK), Michael Pittman (Albany College of Pharmacy and Health Sciences), David Seamon (Kansas State University), Ricki O'Rawe (Queens University, Belfast), and Catharine Christof (Loyola Marymount University). 
I. Gurdjieff: Scholars and Practitioners in Conversation," featuring papers by Joseph Azize, Michael Pittman, Vrasidas Karalis, Jeremy Johnson, Steven J. Sutcliffe, David G. Robertson, and Carole M. Cusack. The purpose of this gathering was a more inclusive approach, including analyses of Gurdjieff's sources and teaching techniques, key texts and contexts for communicating the "message," and orthodox and heterodox continuations of the Work teaching after his death. The Movements and the music Gurdjieff composed with Thomas de Hartmann (1885-1956) featured (Petsche 2015), and practitioners made up the larger part of the audience.

The first article, Joseph Azize's "Did Gurdjieff Write Scripture?," asks if we can gain much from focusing on a category that Gurdjieff did not use-scripture-in the interpretation of his writings. Azize discusses the publication and revision processes of the First Series, Beelzebub's Tales to His Grandson (1999 [1950]) productively in terms of Gurdjieff's ideas about Objective and Subjective Art.

Michael Pittman's contribution, "'Beelzebub in India and Tibet': Continuing Conversations on the Soul in All and Everything," focuses closely on the text as a guide for the pupil who seeks to acquire a soul through "deliberate suffering and conscious labor [sic]" (Gurdjieff 2008 [1933]). Pittman investigates Gurdjieff's evaluation of Hinduism and Buddhism with reference to the soul and potential survival after bodily death.

The third article is Carole M. Cusack's "Pupil Memoirs as Hagiography in the Gurdjieff Work." This study examines texts by Gurdjieff pupils, including those by Margaret Anderson and Kathryn Hulme, in terms of how they explain the process of learning from Gurdjieff, and memorialise the Master for those who have not met him. The memoirs also provide a model of discipleship for later Work pupils to emulate.

The fourth article, Joseph Azize's "Gurdjieff Theologos," tackles major themes in the study of religion, including the nature of God, the soul, the meaning of human life, reincarnation, and divine justice. Azize's focus here is suffering, and the role it can play in assisting God and transforming the creation, as well as providing a way for individuals to develop spiritually from sleep to wakefulness.

The final contribution to the special issue is David Seamon's "Setting Forth a Canon of the Gurdjieff Work." This essay considers what the term "canon" might mean, and how to apply it to the Fourth Way tradition. Seamon concludes that the Gurdjieff canon is an ensemble of texts, methods, and performative media that when, engaged with sincerely and persistently, might facilitate self-transformation psychologically and spiritually. 
My thanks are due to Brad Anderson, the Editor of Postscripts, and to the anonymous referees who provided feedback on the five articles. The staff at Equinox Publishing are always helpful and professional in facilitating the publication of journal issues. I owe a significant debt to Drs Venetia Robertson and Johanna Petsche, who have worked with me on many Gurdjieff-related projects as research assistants for more than a decade.

My deepest gratitude is due to the three colleagues who contributed to this Special Issue, Joseph Azize, David Seamon, and Michael Pittman. I have been fortunate to have Joseph's constant intellectual companionship as we are members of the same academic department at the University of Sydney. David and Michael came to know me online, and I thank them for their confidence and trust in me. I hope that I repay it, daily.

\section{References}

Azize, Joseph. 2013. “"The Four Ideals': A Contemplative Exercise by Gurdjieff." ARIES: Journal for the Study of Western Esotericism 13(2): 173-203. https:// doi.org/10.1163/15700593-13130202

Gurdjieff, George Ivanovich. 1999 [1950]. Beelzebub’s Tales to His Grandson. London and New York: Penguin Arkana.

Moore, James. 1991. Gurdjieff: The Anatomy of a Myth. A Biography. Shaftesbury and Rockport, MA: Element.

Pecotic, David J. and Carole M. Cusack. 2016. “The (World Wide) Work 2.0." Fieldwork in Religion 11(1): 91-103. https://doi.org/10.1558/firn.31891

Petsche, Johanna. 2011. "Gurdjieff and Blavatsky: Western Esoteric Teachers in Parallel". Literature \& Aesthetics 21(1): 98-115. . 2015. Gurdjieff and Music: The Gurdjieff/de Hartmann Piano Music and its Esoteric Significance. Brill: Leiden. https://doi.org/10.1163/9789004284449

Pittman, Michael S. 2012. Classical Spirituality in Contemporary America: The Confluence and Contribution of G. I. Gurdjieff and Sufism. London: Bloomsbury. https://doi.org/10.5040/9781472548474

Rawlinson, Andrew. 1997. The Book of the Enlightened Masters: Western Teachers in Eastern Traditions. Chicago, IL: Open Court.

Seamon, David. 2020. "Understanding the Esoteric through Progressive Awareness: The Case of Gurdjieff's Law of Three as Elaborated by J. G. Bennett's Six Triads." ARIES: Journal for the Study of Western Esotericism 20(1): 81-107. https://doi.org/10.1163/15700593-02001004

Webb, James. 1980. The Harmonious Circle: The Lives and Work of G. I. Gurdjieff, P. D. Ouspensky and Their Followers. London: Thames \& Hudson.

Wellbeloved, Sophia 2005. "Gurdjieff, 'Old' or 'New Age': Aristotle or Astrology?" Journal of Alternative Spiritualities and New Age Studies 1(1): 75-87. 